\title{
Integrin $\beta 3$ Haploinsufficiency Modulates Serotonin Transport and Antidepressant-Sensitive Behavior in Mice
}

\author{
Matthew Mazalouskas, ', Tammy Jessen 1,6, Seth Varney', James S Sutcliffe ${ }^{2,3}$, Jeremy Veenstra-VanderWeele ${ }^{4}$, \\ Edwin H Cook $\mathrm{Jr}^{5}$ and Ana MD Carneiro*,I \\ 'Department of Pharmacology, Vanderbilt University School of Medicine, Nashville, TN, USA; '2Department of Psychiatry, Vanderbilt University \\ School of Medicine, Nashville, TN, USA; ${ }^{3}$ Department of Molecular Physiology and Biophysics, Vanderbilt University School of Medicine, Nashville, \\ TN, USA; ${ }^{4}$ Department of Psychiatry, Columbia University, New York City, NY, USA; ${ }^{5}$ Department of Psychiatry, University of Illinois at Chicago, \\ Chicago, IL, USA
}

\begin{abstract}
Converging lines of evidence have identified genetic interactions between the serotonin transporter (SERT) gene and ITGB3, which encodes the $\beta 3$ subunit that forms the $\alpha \mathrm{llb} \beta 3$ and $\alpha \vee \beta 3$ integrin receptor complexes. Here we examine the consequences of haploinsufficiency in the mouse integrin $\beta 3$ subunit gene (Itgb3) on SERT function and selective 5-hydroxytryptamine (5-HT) reuptake inhibitor (SSRI) effectiveness in vivo. Biochemical fractionation studies and immunofluorescent staining of murine brain slices reveal that $\alpha v \beta 3$ receptors and SERTs are enriched in presynaptic membranes from several brain regions and that $\alpha v \beta 3$ colocalizes with a subpopulation of SERT-containing synapses in raphe nuclei. Notably, we establish that loss of a single allele of Itgb3 in murine neurons is sufficient to decrease 5-HT uptake by SERT in midbrain synaptosomes. Pharmacological assays to elucidate the $\alpha v \beta 3$-mediated mechanism of reduced SERT function indicate that decreased integrin $\beta 3$ subunit expression scales down the population size of active SERT molecules and, as a consequence, lowers the effective dose of SSRIs. These data are consistent with the existence of a subpopulation of SERTs that are tightly modulated by integrin $\alpha v \beta 3$ and significantly contribute to global SERT function at 5-HT synapses in the midbrain. Importantly, our screen of a normal human population for single nucleotide polymorphisms in human ITGB3 identified a variant associated with reductions in integrin $\beta 3$ expression levels that parallel our mouse findings. Thus, polymorphisms in human ITGB3 may contribute to the differential responsiveness of select patients to SSRIs.
\end{abstract}

Neuropsychopharmacology (20I5) 40, 20I5-2024; doi:I0.I038/npp.20I5.5I; published online II March 2015

\section{INTRODUCTION}

Serotonin (also known as 5-hydroxytryptamine (5-HT)) plays important functional roles in the gastrointestinal tract, cardiovascular system, and the central nervous system (CNS). Dysfunctional 5-HT homeostasis and neurotransmission within the CNS has been associated with major depression, anxiety, obsessive-compulsive disorder, drug abuse, and autism-spectrum disorders (Cook and Leventhal, 1996; Ruhe et al, 2007). Used to treat depression and anxieties, selective 5-HT reuptake inhibitors (SSRIs) exert their neuromodulatory effects by binding to and inhibiting the function of the 5-HT transporter (also known as 5-HTT, SERT). SERTmediated removal of extracellular 5-HT plays an important role in the repackaging of 5-HT into presynaptic vesicles and restricts the availability of 5-HT to activate pre- and post-

\footnotetext{
*Correspondence: Dr AMD Carneiro, Department of Pharmacology, Vanderbilt University School of Medicine, 461 Preston Research Building, 23rd Avenue South at Pierce, Nashville, TN 37232, USA, Tel: + | 615875 5635, Fax: 615-343-1084,

E-mail: ana.carneiro@vanderbilt.edu

${ }^{6}$ These authors contributed equally to this work.

Received 20 August 2014; revised 6 February 2015; accepted 8 February 2015; accepted article preview online 16 February 2015
}

synaptic 5-HT receptors (Blakely et al, 1998). Although the immediate effects of SSRI dosing include dramatic increases in extracellular 5-HT and activation of post-synaptic 5-HT receptors (Ramaiya et al, 1997), the therapeutic effects of SSRIs are associated with long-term exposure that includes desensitization of 5-HT auto-receptors and alterations in synaptic structure and function (Mayorga et al, 2001). Therefore, SSRI effectiveness depends on both proximal (eg, SERT and 5-HT receptors) and distal factors (eg, synaptic plasticity, synaptogenesis, and neurogenesis).

Blood 5-HT levels are utilized as an endophenotype for neuropsychiatric disorders in humans (DeLisi et al, 1981; Cook and Leventhal, 1996; Cleare, 1997; Askenazy et al, 1998; Verkes et al, 1998; Ma et al, 2007; Wulsin et al, 2009). The ITGB3 gene, coding for the integrin $\beta 3$ subunit, has been consistently identified as a quantitative locus for regulating whole blood 5-HT levels (Weiss et al, 2004, 2006a; Coutinho et al, 2007; Cross et al, 2008). The platelet integrin $\alpha \operatorname{IIb} \beta 3$ receptor (also known as glycoprotein IIb/IIIa) was discovered to directly interact with SERT and modulate SERTmediated uptake of extracellular 5-HT (Carneiro et al, 2008). A large family of obligatory, heterodimeric glycoproteins composed of an $\alpha$ chain and a $\beta$ chain, integrin receptors mediate cell-cell/cell-matrix interactions and have 
important functional roles in neurons regulating axon growth, guidance, and regeneration as well as synaptic structural changes associated with synaptic activity (Chavis and Westbrook, 2001; Milner and Campbell, 2002; Nikonenko et al, 2003; Pozzi and Zent, 2003; Cingolani et al, 2008). Recently, our laboratory examined the genetic interaction between the murine Itgb3 and the SERT (Slc6a4) genes and identified a functional decrease in SERT-mediated 5-HT uptake in synaptoneurosomes from the midbrain and cortex, but not from the hippocampus, of $\mathrm{Itgb3}^{+/-}$mice (Whyte et al, 2014). This study implicates a conserved role for the integrin $\beta 3$ subunit in the modulation of SERT function in the periphery and in the CNS, where the integrin $\beta 3$ subunit associates with the integrin $\alpha \mathrm{v}$ subunit to form the vitronectin receptor (ie, $\alpha \mathrm{v} \beta 3$ ).

Given the convergent evidence of the integrin $\beta 3$ subunit in the modulation of serotonergic signaling, we examined the localization of integrin $\alpha \mathrm{v} \beta 3$ receptors and the mechanism(s) through which integrin $\alpha \mathrm{v} \beta 3$ receptors regulate SERT function in the midbrain. In this report, we demonstrate the expression of $\alpha \mathrm{v} \beta 3$ receptors in neurons within and outside of the raphe nuclei of the murine midbrain and their enriched localization to the presynaptic terminals of neurons within several brain regions. In the midbrain, $\alpha \mathrm{v} \beta 3$ receptors co-localize with a subpopulation of serotonergic synapses, which exhibit decreased 5-HT uptake in mice containing a heterozygous reduction in integrin $\beta 3$ subunit expression. Assays to elucidate the integrin-mediated mechanism indicate that fewer molecules of SERT are active when $\alpha \mathrm{v} \beta 3$ receptor levels decrease. In support of this, $\operatorname{Igb3^{+/-}}$ mice, predicted to have a smaller population of active SERT, required a lower effective dose of SSRI in tail suspension tests (TSTs). Last, we identify a common polymorphism in human ITGB3 that reduces integrin $\beta 3$ subunit expression, suggesting that polymorphisms in human ITGB3 can contribute to the differential responsiveness of select patients to SSRIs.

\section{MATERIALS AND METHODS}

\section{Reagents}

R/S citalopram hydrobromide, paroxetine hydrochloride hemihydrate, and 5-HT (5-hydroxytryptamine creatinine sulfate complex) were purchased from Sigma (St Louis, MO). Radioligands were purchased from PerkinElmer Life Sciences (Waltham, MA). Purified $\alpha \mathrm{v} \beta 3$ was purchased from Chemicon International (Millipore, Billerica, MA). Antibody sources: rabbit anti-mouse integrin $\beta 3$ and PSD-95: Cell Signaling Technology (Denvers, MA); mouse anti-integrin $\alpha \mathrm{v}$ : BD Biosciences (San Jose, CA); mouse anti-neuronal nuclei (NeuN), SNAP25, synaptophysin, and NMDAR: Chemicon International; guinea-pig anti-SERT: Frontier Science (Hokkaido, Japan).

\section{Animals}

Mouse studies were performed in accordance with humane guidelines established by the Vanderbilt Institutional Animal Care and Use Committee (IACUC) under approved protocols $(\mathrm{M} / 12 / 167)$. Mice used in this study were males generated from $\operatorname{Itgb3}^{+/+} \times \mathrm{Itgb3}^{+/-}$crosses originated from an Itgb3 null line, provided by Dr Hynes at MIT (Hodivala-Dilke et al, 1999), which were backcrossed over 20 generations to C57BL/6. Mice were group-housed with their littermates and maintained on a 12-h light-dark cycle and provided with food and water ad libitum.

\section{Immunofluorescence}

Mice (9 $\mathrm{Itgb3}^{+/+}$and $4 \mathrm{Itgb3}^{-/-}$) were perfused with $30 \mathrm{ml}$ $4 \%$ paraformaldehyde (Sigma). Brains were stored in $30 \%$ sucrose for $48 \mathrm{~h}$ at $4{ }^{\circ} \mathrm{C}$, and then stereotaxically sectioned every $30 \mu \mathrm{m}$ on a frozen stage microtome (Leica) and stored in a cryoprotectant solution (30\% ethylene glycol, $30 \%$ glycerol in phosphate-buffered saline (PBS)). Sections collected between $\sim 4$ and $5 \mathrm{~mm}$ from Bregma were defined as midbrain sections. Immediately before use, serial sections were washed in tris-buffered saline (TBS). Slices were treated with $\mathrm{Na}^{+} /$citrate solution $(10 \mathrm{mM}$ tri-sodium citrate dihydrate, $\mathrm{pH} 6.0$ containing $0.05 \%$ Tween-20) at $50{ }^{\circ} \mathrm{C}$ for $5 \mathrm{~min}$. Endogenous peroxidase was quenched by incubating sections in $1 \% \mathrm{H}_{2} \mathrm{O}_{2}$ for $30 \mathrm{~min}$. Slices were blocked with blocking buffer ( $1 \times$ TBS containing $5 \%$ goat serum, $1 \%$ bovine serum albumin, and $0.25 \%$ Triton $\mathrm{X}-100$ ) for $1 \mathrm{~h}$ at room temperature. Primary antibodies were added at a $1: 250$ dilution in blocking buffer and incubated for $16 \mathrm{~h}$ at $4{ }^{\circ} \mathrm{C}$. Integrin $\beta 3$ signal was amplified by preincubating biotinylated antirabbit antibody with streptavidin-conjugated horseradish peroxidase (both diluted at 1:500 in blocking buffer) for $15 \mathrm{~min}$ at room temperature, followed by incubation with slices for $1 \mathrm{~h}$ at room temperature. After washing with $1 \times$ TBS, slices were incubated with tyramide solution (TSA Biotin Plus Tyramide Reagent; Perkin Elmer, CA) for $10 \mathrm{~min}$. After washing with $1 \times$ TBS, fluorescent secondary antibodies (goat anti-mouse-Cy5, streptavidin-Cy2, and goat anti-guinea-pig-Cy3; Jackson ImmunoResearch Laboratories, West Grove, PA) were applied at a 1:500 concentration for $16 \mathrm{~h}$ at room temperature. Slices were washed in $1 \times$ TBS and mounted onto slides using Aqua-Poly/Mount (Polysciences, Warrington, PA). Wide field images were captured using a Nikon AZ $100 \mathrm{M}$ microscope. Confocal images were captured using a $1 \mu \mathrm{m}$ pinhole on a Zeiss LSM 510 Meta confocal and prepared using the LSM 5 Image Browser (Zeiss, Erie, PA). Z-series of 12-15 images from $0.125 \mu \mathrm{m}$ optical slices were acquired using a DeltaVision OMX super resolution microscope (GE Healthcare, Issaquah, Washington). Reconstruction of 3D-SIM images and 3D modeling was performed using softWorX software. Image acquisition and analysis were performed in part through the use of the VUMC Cell Imaging Shared Resource (supported by NIH grants CA68485, DK20593, DK58404, DK59637, and EY08126).

\section{Isolation of Presynaptic Membranes}

Synaptoneurosomes and membrane fractions were prepared as described previously (Phillips et al, 2001). In brief, mouse tissue was homogenized in $0.32 \mathrm{M}$ sucrose containing $0.1 \mathrm{mM} \mathrm{CaCl}_{2}$ and $1 \mathrm{mM} \mathrm{MgCl}_{2}$ using a Teflon-glass tissue homogenizer (Wheaton Instruments, Millville, NJ). The homogenized tissue was centrifuged at $1000 \mathrm{~g}$ for $10 \mathrm{~min}$ at $4^{\circ} \mathrm{C}$ and synaptoneurosomes collected by centrifugation at $10000 \mathrm{~g}$ for $10 \mathrm{~min}$ at $4^{\circ} \mathrm{C}$. Synaptoneurosomes were lysed and non-synaptic proteins extracted by resuspending pellets in $20 \mathrm{mM}$ Tris- $\mathrm{HCl}$ ( $\mathrm{pH} 6.0$ containing $0.1 \mathrm{mM} \mathrm{CaCl}_{2}, 1 \mathrm{mM}$ 
$\mathrm{MgCl}_{2}$, and $0.1 \%$ Triton X-100) and immediate centrifugation at $100,000 \mathrm{~g}$ for $30 \mathrm{~min}$ at $4{ }^{\circ} \mathrm{C}$. The pellet was then solubilized in $20 \mathrm{mM}$ Tris- $\mathrm{HCl}(\mathrm{pH} 8.0$ and $1 \%$ Triton $\mathrm{X}-100$ ) and incubated on ice for $15 \mathrm{~min}$ to extract presynaptic proteins. Postsynaptic proteins were separated by centrifugation at $10000 \mathrm{~g}$ for $30 \mathrm{~min}$ at $4{ }^{\circ} \mathrm{C}$ and solubilized in Laemmli buffer for western blot analysis.

\section{Synaptosomal Uptake and Binding Measures}

Saturation kinetic and competition analyses of 5-HT uptake were performed on crude synaptosomal pellets prepared after homogenization in $0.32 \mathrm{M}$ sucrose with $4 \mathrm{mM}$ HEPES, $\mathrm{pH} 7.4$ to remove post-synaptic membranes. The synaptosomal pellet was resuspended in uptake buffer $(1 \times \mathrm{KRH}$ (130 mM NaCl, $1.3 \mathrm{mM} \mathrm{KCl}, 2.2 \mathrm{mM} \mathrm{CaCl}_{2}, 1.2 \mathrm{mM} \mathrm{MgSO}_{4}$, and $1.2 \mathrm{mM} \mathrm{KH}_{2} \mathrm{PO}_{4}$ ) containing $1.8 \mathrm{~g} / \mathrm{L}$ glucose, $10 \mathrm{mM}$ HEPES, $100 \mu \mathrm{M}$ pargyline, and $100 \mu \mathrm{M}$ ascorbic acid). For saturation analysis, we incubated $25 \mu \mathrm{g}$ of synaptosomes with increasing concentrations of 5-HT (12.5-400 nM) for $10 \mathrm{~min}$ at $37^{\circ} \mathrm{C}$. Uptake was terminated by filtration through polyethyleneimine-coated GF/B Whatman filters using a Brandel Cell Harvester (Brandel, Gaithersburg, MD). Filters were washed three times with ice-cold $1 \times \mathrm{KRH}$ buffer and immersed in scintillation liquid for $8 \mathrm{~h}$ before quantification of accumulated radioactivity by scintillation spectrometry (Beckman Coulter, Fullerton, CA). Counts obtained from the filtered samples were corrected for nonspecific uptake using parallel samples incubated at $37^{\circ} \mathrm{C}$ with $1 \mu \mathrm{M}$ paroxetine. Data from different experiments were combined by normalizing each $\operatorname{Itgb3} 3^{+/-}$curve to its corresponding $\operatorname{Itgb3}{ }^{+/+}$ control, where the data point at $100 \mathrm{nM}$ 5-HT was considered $100 \%$. Competition binding assays to assess 5HT potency for $\left[{ }^{3} \mathrm{H}\right] \mathrm{MPP}^{+}$uptake or SSRI potency for inhibition of $\left[{ }^{3} \mathrm{H}\right] 5-\mathrm{HT}$ uptake were performed as described in Henry et al, (2006). In brief, $25 \mu \mathrm{g}$ synaptosomes were preincubated at $37^{\circ} \mathrm{C}$ in a shaking water bath with increasing concentrations of competitor ( $1 \mathrm{pM}-1 \mathrm{mM})$. After $10 \mathrm{~min}$, $20 \mathrm{nM}$ of the radiolabeled substrate was added, and samples incubated at $37^{\circ} \mathrm{C}$ for an additional $10 \mathrm{~min}$. Data were analyzed by using one-site competition binding parameters to calculate $\mathrm{IC}_{50}$ values.

We quantified the binding of the high affinity cocaine analog [ $\left.{ }^{125} \mathrm{I}\right] \mathrm{RTI}-55(5 \mathrm{nM})$ to intact crude synaptosomes $(25 \mu \mathrm{g})$ and binding of $\left[{ }^{3} \mathrm{H}\right] 5$ - $\mathrm{HT}(20 \mathrm{nM})$ to presynaptic membranes at $4{ }^{\circ} \mathrm{C}$ for 20 min in modified PBS (pH 7.4, containing $0.1 \mathrm{mM} \mathrm{CaCl}$ and $1.0 \mathrm{mM} \mathrm{MgCl}_{2}$ ) in the presence or absence of a membrane-permeant $(1 \mu \mathrm{M}$ paroxetine) or membrane-impermeant $(100 \mu \mathrm{M} \quad 5-\mathrm{HT})$ displacer, defining total and surface-specific binding, respectively (Zhu et al, 2004, 2006). To perform saturation analysis of $\left[{ }^{3} \mathrm{H}\right]$ citalopram binding, crude synaptosomal pellets $(\sim 50 \mu \mathrm{l})$ were resuspended in 10 volumes of water with protease inhibitors and then equilibrated to $50 \mathrm{mM}$ Tris, $\mathrm{pH}$ 7.4. After a $20 \mathrm{~min}$ incubation with rotation at $4{ }^{\circ} \mathrm{C}$, samples were spun $15000 \mathrm{~g}$ for $25 \mathrm{~min}$ at $4^{\circ} \mathrm{C}$. Pellets containing purified plasma membranes were resuspended in binding buffer $(50 \mathrm{mM}$ Tris, $\mathrm{pH} 7.4,120 \mathrm{mM} \mathrm{NaCl}$, and $5 \mathrm{mM}$ $\left.\mathrm{MgCl}_{2}\right)$. Purified membranes $(43 \mu \mathrm{g})$, preincubated in the absence or presence of $1 \mu \mathrm{M}$ paroxetine for $30 \mathrm{~min}$ at $4{ }^{\circ} \mathrm{C}$, were incubated with increasing concentrations of $\left[{ }^{3} \mathrm{H}\right]$ citalopram $(0.625-100 \mathrm{nM})$ for $20 \mathrm{~min}$ at $4^{\circ} \mathrm{C}$. Binding was terminated by filtration as described above. All binding experiments were performed in duplicates using four or more mice.

\section{Tail Suspension Test}

An automated TST device (Med Associates, St Albans, VT) was used to measure the duration of behavioral immobility. Mice were suspended by the tail with tape to a vertical aluminum bar connected to a strain gauge. Before attaching the tail to the bar, each mouse had its tail passed through a clear $3 \mathrm{~cm}$ plastic tube to prevent mice from climbing their own tails. The following settings were used in all experiments: threshold 1: 7; gain: 8; time constant: 0.25; and resolution: $200 \mathrm{~ms}$. Citalopram was prepared fresh daily by dissolving the powder in deionized water and diluted in $0.9 \%$ saline. Drug was administered by intraperitoneal injection in a volume of $0.01 \mathrm{ml} / \mathrm{g}$ body weight and the dose was $0,2,5$, or $10 \mathrm{mg} / \mathrm{kg}$ calculated as the weight of the base. Each mouse was tested four times in the TST, with 1 week between testings. A counterbalanced design was used, where half of the animals of each genotype received citalopram in one order and the other half followed another order. No effects of multiple testing were observed. Mice were injected with drug or saline $30 \mathrm{~min}$ before a $6 \mathrm{~min}$ TST. A second cohort of mice was used to test immobility responses to paroxetine. In this cohort, mice received saline or paroxetine $(5 \mathrm{mg} / \mathrm{kg})$ via intraperitoneal injection and were then tested in the TST after $30 \mathrm{~min}$. Data was analyzed by two-way ANOVA over the 6-min period (drug $\times$ genotype).

\section{Western Blot of Human Platelet Samples}

Human blood of ITGB3 genotyped subjects was collected under an approved institutional review board protocol (the University of Illinois at Chicago) (Hammock et al, 2012). All subjects provided informed consent for research studies. Whole blood was collected and frozen at $-80^{\circ} \mathrm{C}$ for shipping and analysis at Vanderbilt. Samples were thawed and resuspended in $1 \mathrm{ml} \mathrm{H}_{2} \mathrm{O}$ for lysis of red blood cells. The remaining platelets were collected by centrifugation at 15 $000 \mathrm{~g}$ for $30 \mathrm{~min}$ and washed $2 \times$ with $1 \times$ PBS. Platelets were counted in a hemacytometer. Protein was extracted in $1 \%$ sodium dodecyl sulfate in PBS pH 7.4 containing protease inhibitor cocktail (containing AEBSF, aprotinin, bestatin, E-64, leupeptin, and pepstain A; Sigma-Aldrich, Saint Louis, MO). Protein was measured using a modified Lowry protocol with bicinchoninic acid (BCA Protein Assay Kit, Pierce Chemical Company, Rockford, IL). Protein extracts $(25 \mu \mathrm{g})$ were submitted to SDS-PAGE and western blot analysis with chemiluminescence. Amersham Hyperfilm ECL films were exposed at $1,5,10$, and $30 \mathrm{~min}$ to address linearity of the data (GE Healthcare, Pittsburgh, PA). Films were scanned in tagged image file format (.tiff) and bands quantified by densitometry using ImageJ. Data is presented as raw values normalized to the mean of the most common genotype. Gaussian distribution of the data was examined by D'Agostino \& Pearson omnibus normality test. Data was analyzed using one-way ANOVA (for normally distributed data) or Kruskal-Wallis test (non-parametric analysis), when necessary. Dunn's multiple comparisons test was performed when appropriate, comparing the mean rank of each 
genotype with the mean rank of all other genotypes, with each $P$-value adjusted for multiple comparisons $(\alpha=0.05)$. Allele frequencies in our data set were compared with dbSNP frequencies as reported in Table 1.

\section{Data Analyses}

All data was analyzed using GraphPad Prism software (Prism 6, GraphPad software, LaJolla, CA). Michaelis-Menten curve fit as a function of ligand concentration revealed $K_{\mathrm{m}}$ and $V_{\max }$ values in uptake and $K_{\mathrm{d}}$ and $B_{\max }$ in binding experiments, respectively. Statistical analyses are described in the figure legends.

\section{RESULTS}

\section{Integrin $\alpha v \beta 3$ Is Expressed in Raphe Neurons}

To establish a role for integrin $\alpha \mathrm{v} \beta 3$ receptors in the modulation of SERT function in the CNS, we first examined the cellular distribution of integrin $\alpha \mathrm{v} \beta 3$ receptors within the murine midbrain by immunofluorescent staining. Given that the $\alpha \mathrm{v}$ subunit can associate with other integrin $\beta$ subunits (including $\beta 1, \beta 5, \beta 6$, and $\beta 8$ ), but the $\beta 3$ subunit is restricted in its association with the $\alpha \mathrm{v}$ subunit in the CNS, we utilized integrin $\beta 3$ subunit specific antibodies to label $\alpha \mathrm{v} \beta 3$ receptors in midbrain slices of brains isolated from $\operatorname{Itgb3}^{+/+}$and Itgb3 $^{-/-}$littermates. Co-staining Itgb3 $^{+/+}$midbrain slices (Bregma $-4.60 \mathrm{~mm}$ ) with anti-integrin $\beta 3$ and anti-NeuN antibodies revealed that $\alpha \mathrm{v} \beta 3$ receptors were expressed in neurons (Figure 1a). The integrin $\beta 3$ subunit antibody failed to stain slices from $\operatorname{Itgb3}^{-/-}$mice, as well as $\operatorname{Itgb3}^{+/+}$slices preincubated with purified $\alpha v \beta 3$, thus validating the specificity of this antibody (Figure $1 \mathrm{~b}$ and data not shown). Further examination of integrin $\beta 3$ subunit expression within serial sections of $\operatorname{Itgb3}^{+/+}$midbrains revealed that $\alpha \mathrm{v} \beta 3$ receptors were expressed in several regions, including the dorsal and median raphe nuclei where serotonergic neurons are located (Figure 1c).

\section{Integrin $\alpha v \beta 3$ Co-localizes with SERT in Adult Mouse Fibers}

To examine the subcellular distribution of $\alpha \mathrm{v} \beta 3$ receptors in raphe neurons and their spatial relationship to SERT, we stained midbrain sections with antibodies recognizing the integrin $\beta 3$ subunit, SERT, and the presynaptic marker synaptophysin. Using confocal microscopy, we observed integrin $\beta 3$ subunit immunoreactivity in the cell bodies and fibers of neurons localized to the dorsal raphe, the latter of which also stained positive for SERT expression (Figure 2a1). We found that expression of SERT (SERT+) partially co-localized with expression of synaptophysin (Synapt + ), indicating that some, but not all transporters were localized to presynaptic terminals. As indicated in the higher magnification image, populations of Synapt+/SERT+ puncta were identified where $\alpha \mathrm{v} \beta 3$ receptors were absent (Figure 2a2; letters a-c) or present (Figure 2a2; numbers 1-3). Employing structured illumination microscopy, we observed overlap of SERT and integrin $\beta 3$ subunit signals on structures measuring $\sim 0.150 \mu \mathrm{m}$ (Figure 2b1,2,3). Three-dimensional reconstruction (Figure 2b4, Supplementary Movie) revealed co-localization of SERT and $\alpha \mathrm{v} \beta 3$ within organelles of $\sim 1 \mu \mathrm{m}$ diameter, consistent with the diameter of 5-HT synaptic terminals (arrow; Figure 2b5) (Arai et al, 2002) and at subcellular compartments of $0.1-0.2 \mu \mathrm{m}$ along the fibers, possibly intracellular vesicles (arrowhead; Figure 2b7).

To further define the synaptic localization of integrin $\alpha v \beta 3$ receptors in neurons, we utilized a $\mathrm{pH}$-dependent solubility shift fractionation technique that allows for the separation of presynaptic active zones from post-synaptic densities (Phillips et al, 2001). Western analysis of fractions generated from cerebellum $(\mathrm{Cb})$, midbrain $(\mathrm{Mb})$, hippocampus (Hp), thalamus (Th), and striatum (St) demonstrated robust synaptic segregation, noted by the enrichment of the presynaptic protein synaptophysin alongside a relative exclusion of postsynaptic markers (NMDAR and PSD-95) in the presynaptic fractions (Figure 2c). Furthermore, these data revealed that $\alpha \mathrm{v}$ and $\beta 3$ subunits, together with SERT, were expressed in the presynaptic nerve terminals of several brain regions, including the midbrain (Figure 2c). Collectively, our studies suggest that two distinct populations of serotonergic synapses are present in the raphe and distinguished by co-localization of SERT with or without $\alpha \mathrm{v} \beta 3$ receptors.

\section{Integrin $\beta 3$ Haploinsufficiency Influences SERT- Mediated 5-HT Transport Velocity and Not Affinity}

Data from our laboratory indicated that $\operatorname{Igb3}^{+/-}$mice exhibit reduced midbrain 5-HT uptake activity (Whyte et al, 2014). Here, we utilized synaptosomal preparations, devoid of postsynaptic terminals, to elucidate the mechanism(s) by which $\alpha \mathrm{v} \beta 3$ receptors modulate SERT function. Synaptosomes isolated from the midbrains of $\mathrm{Itgb3}^{+/-}$mice expressed significantly lower levels of the integrin $\beta 3$ subunit when compared with synaptosomes prepared from $\operatorname{Igb3}^{+/+}$ littermates (Figure 3a). No change in integrin $\alpha \mathrm{v}$ subunit expression was observed. We assessed any genotype-specific differences in SERT function by collating and normalizing saturating curves from multiple 5-HT uptake experiments. As illustrated in the representative experiment, $\operatorname{Itgb3}^{+/-}$ synaptosomes exhibited decreased uptake of 5-HT when compared with $\operatorname{Itgb3}^{+/+}$synaptosomes (Figure $3 \mathrm{~b}$ ). The pooled data demonstrated a $40 \%$ reduction in SERT-mediated 5-HT $V_{\max }$ and no change in the transporter's affinity $\left(K_{\mathrm{m}}\right)$ for 5HT (Figure 3c and d). We also examined the ability of 5-HT to inhibit the uptake of 1-methyl-4-phenylpyridinium (also known as $\mathrm{MPP}^{+}$) and observed no difference in 5-HT potency between genotypes (Figure $3 \mathrm{e}$ ). In total, these data demonstrated that integrin $\alpha \mathrm{v} \beta 3$-mediated regulation of SERT 5-HT transport velocity can be modulated by changes in integrin $\beta 3$ subunit expression.

\section{Integrin $\alpha v \beta 3$ Receptors Control Active SERT Population Numbers}

Alterations in transporter expression, trafficking/recycling, and/or catalytic function could affect the kinetic properties of SERT and account for the decrease in $V_{\max }$ observed in Itgb3 $^{+/-}$synaptosomes. To evaluate if altered expression or trafficking/recycling rates of SERT were occurring, we performed radioligand displacement assays using [ ${ }^{125}$ I]RTI-55 and SERT-selective lipophilic (ie, paroxetine) or hydrophobic (ie, 5-HT) competitors to define the total and plasma- 
a
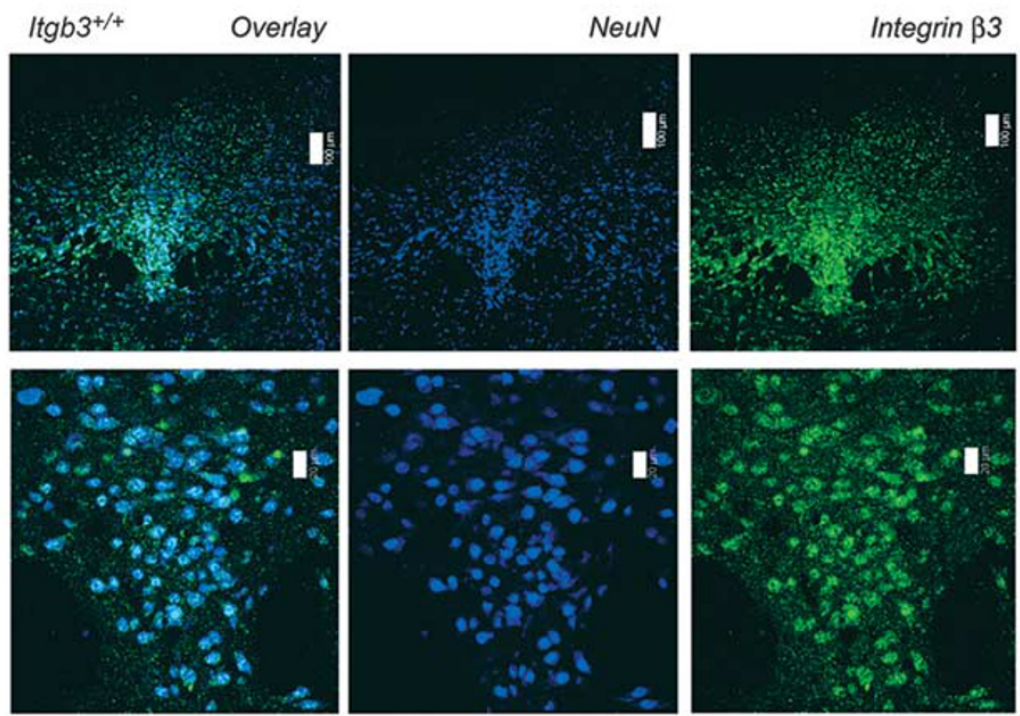

b
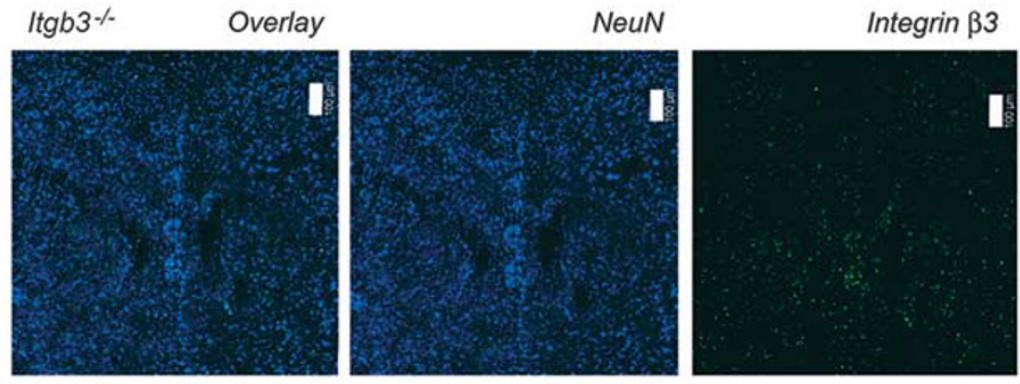

C
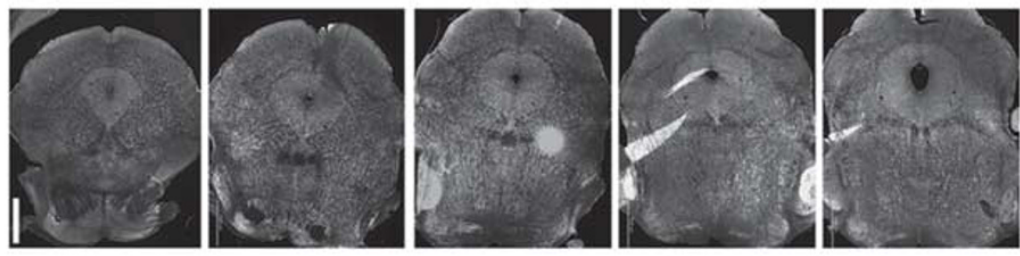

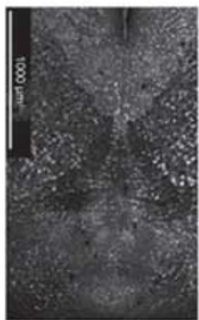

Bregma:

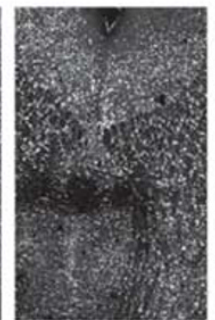

$-4.34$

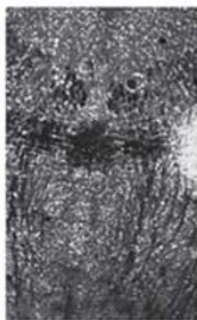

$-4.64$

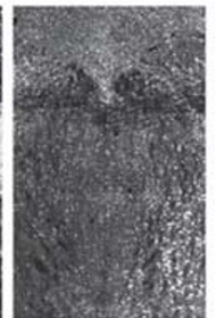

$-4.72$

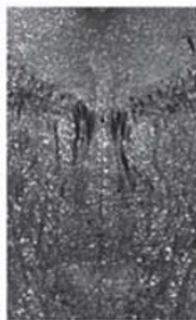

$-4.96$

Figure I Integrin $\alpha \vee \beta 3$ receptors are expressed in raphe neurons. (a and b) Representative images detailing the cellular localization of NeuN (blue) and integrin $\beta 3$ subunit (green) together (Overlay) and individually in a midbrain slice (Bregma $-4.60 \mathrm{~mm}$ ), from an $1 \mathrm{tgb} 3^{+/+}$(a) or $1 \operatorname{tgb} 3^{-1-}(\mathrm{b})$ mouse, immunostained, and visualized using confocal microscopy. Magnification: $\times 20$. Top panels in a and b, bar $=100 \mu \mathrm{m}$. Bottom panels in a, bar $=20 \mu \mathrm{m}$. (c) Immunofluorescent images of stereotaxic slices from an $\operatorname{ltgb} 3^{+/+}$midbrain stained for the integrin $\beta 3$ subunit. Top panels: magnification: $\times 2.5$. $\mathrm{Bar}=1000 \mu \mathrm{m}$. Bottom panels: increased magnification of the dorsal and median raphe nuclei. Magnification: $\times 10$. Bar $=1000 \mu \mathrm{m}$. Figures are representative images of $n=3$ in each genotype. NeuN, neuronal nuclei.

membrane localized SERTs, respectively (Zhu et al, 2010). Both $\operatorname{Itgb3}^{+/+}$and $\operatorname{Itgb3}^{+/-}$synaptosomes were found to express similar levels of total and surface-bound SERT (Figure 4a). In parallel with our displacement assays, we biochemically isolated presynaptic plasma membrane fractions from midbrain synaptosomes and analyzed SERT expression by western blot. Consistent with our binding studies, no Itgb3 genotype-dependent changes in SERT levels at the synaptic surface were observed (Figure $4 \mathrm{~b}$ ), suggesting that the reduced 5-HT uptake capacity in Itgb3 ${ }^{+/-}$mice does not result from 

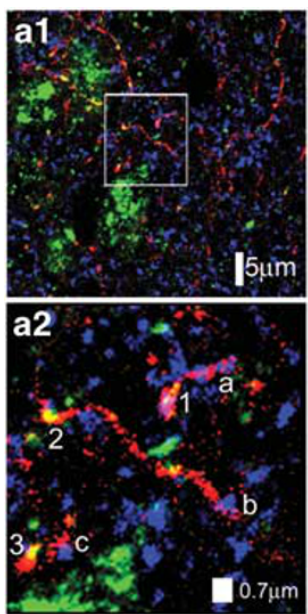
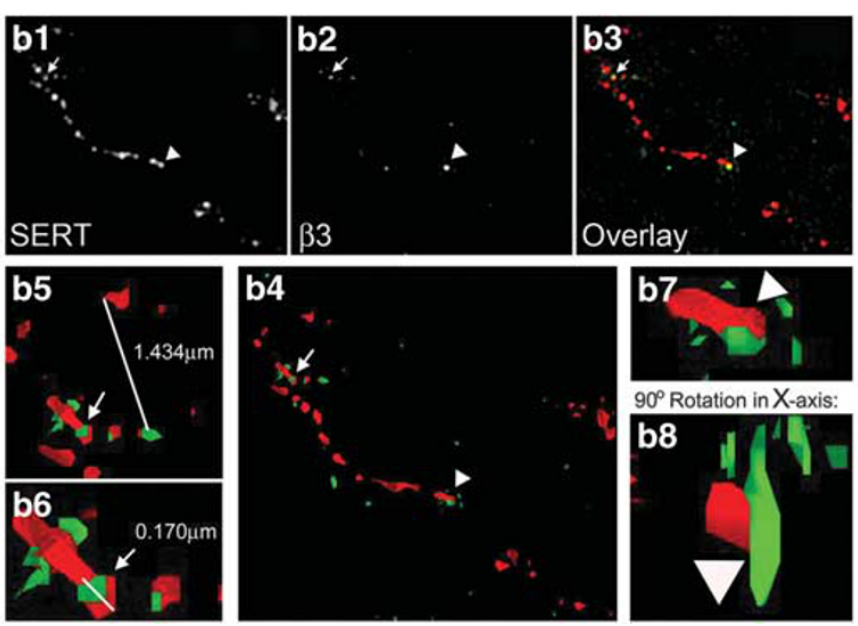

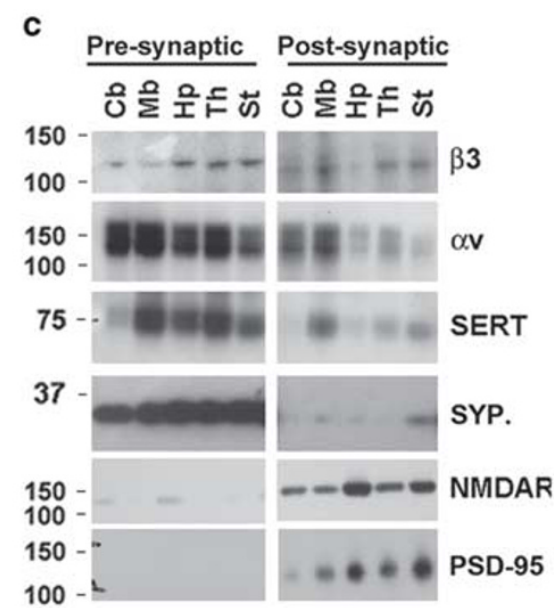

Figure 2 Integrin $\alpha \vee \beta 3$ receptors partially co-localize with SERT in presynaptic terminals. (al) Representative image detailing the distribution of

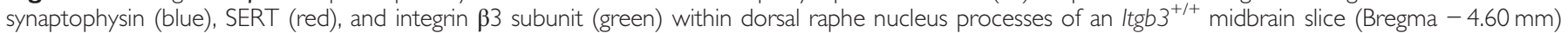

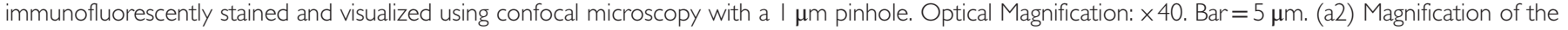

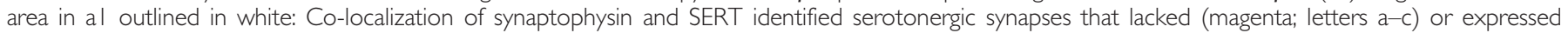

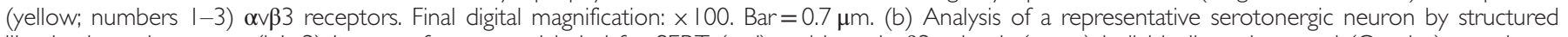

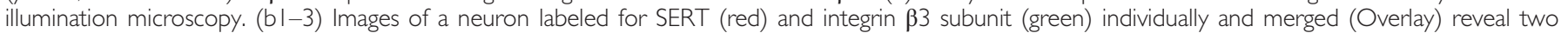

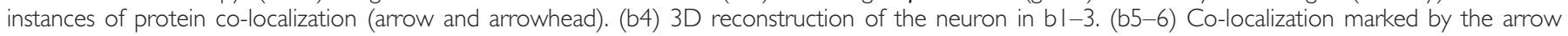

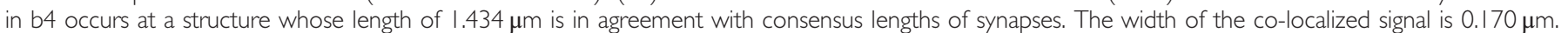

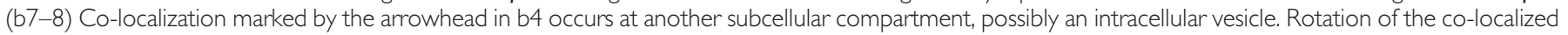

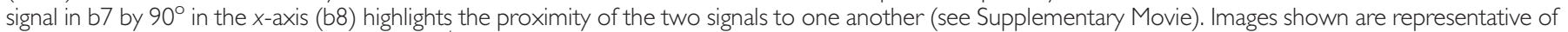

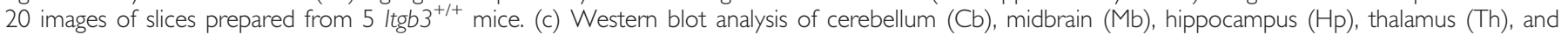

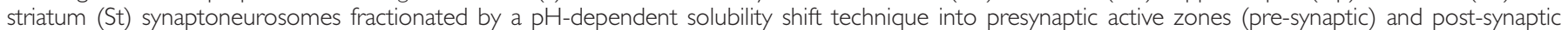

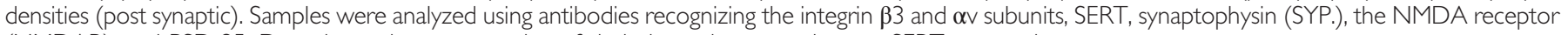
(NMDAR), and PSD-95. Data shown is representative of six independent experiments. SERT, serotonin transporter.

decreased expression of SERT or changes in the trafficking/ recycling of SERT to the neuronal plasma membrane.

To delineate whether alterations in SERT catalytic function could explain the decrease in $V_{\max }$ in $\operatorname{Itgb3}^{+/-}$synaptosomes, we combined the 5-HT uptake data provided in Figure $3 \mathrm{c}$ with $B_{\max }$ estimates, derived from saturation $\left[{ }^{3} \mathrm{H}\right]$ citalopram binding assays of purified plasma membranes, to estimate the 5-HT turnover rate for SERT in each genotype. The $\left[{ }^{3} \mathrm{H}\right]$ citalopram binding curves shown in Figure $4 \mathrm{c}$ yielded turnover rates (ie, $V_{\max } / B_{\max }$ ) of 0.0064 and 0.0060 for SERT in $\operatorname{Igb3}^{+/+}$and $\operatorname{Itgb3}{ }^{+/-}$, respectively. These data suggest that the catalytic function of active SERT molecules is similar in both genotypes.

One possible explanation for the observed reduction in $V_{\max }$ without diminishments in surface SERT levels or turnover rates is a decrease in the population of active SERT molecules. As our microscopy studies revealed the existence of two SERT populations distinguished by their co-localization with $\alpha \mathrm{v} \beta 3$ receptors, we hypothesized that loss of integrin $\beta 3$ subunit expression inactivates a pool of $\alpha \mathrm{v} \beta 3$-associated SERTs. Given that the $B_{\max }$ values exhibited a strong trend toward a significant difference (Figure 4c), suggesting that fewer active SERTs were available to bind $\left[{ }^{3} \mathrm{H}\right]$ citalopram, we examined the binding of $\left[{ }^{3} \mathrm{H}\right] 5-\mathrm{HT}$ in presynaptic plasma membrane fractions. Analysis of these surface purified SERTs revealed a reduction in $\left[{ }^{3} \mathrm{H}\right] 5-\mathrm{HT}$ binding in $\operatorname{Itgb3}^{+/}$preparations (Figure 4d).

Based on our ex vivo findings, we predicted that a lower dose of SSRI would be effective in altering behaviors in mice in TST. The dose-response curve for acutely administered citalopram revealed that, while $10 \mathrm{mg} / \mathrm{kg}$ citalopram elicited decreases in immobility in the TST in both genotypes, $5 \mathrm{mg}$ / $\mathrm{kg}$ produced a significant reduction in immobility in $\operatorname{Itgb3}^{+/}$ mice without affecting Itgb3 ${ }^{+/+}$mice (Figure $4 \mathrm{e}$ ). We found no significant genotype effects for basal immobility (Carter et al, 2011). Similar effects were observed in the TST when a second cohort of mice was exposed to $5 \mathrm{mg} / \mathrm{kg}$ paroxetine (Figure 4f). These changes do not appear to arise from altered in vitro potency of SSRIs to inhibit 5-HT transport, as both SSRIs displayed equivalent potency for SERT in synaptosomes from Itgb3 ${ }^{+/}$and wild-type littermates (Citalopram: Itgb3 ${ }^{+/+}: \log _{\mathrm{IC} 50}$ : $-8.21 \pm 0.36$, $n=6$. Itgb3 ${ }^{+/-}: \log _{\mathrm{IC} 50}:-8.13 \pm 0.38, n=5$. Paroxetine: $\operatorname{Itgb3}{ }^{+/+}: \log _{\mathrm{IC} 50}:-8.71 \pm 0.16, n=5 . \quad \operatorname{Itgb3} 3^{+/-}: \log _{\mathrm{IC} 50}$ : $-8.84 \pm 0.16, n=5)$. Taken together, our behavioral assays suggest that $\alpha \mathrm{v} \beta 3$ receptors define a subpopulation of SERTs, which have high uptake capacity and may represent the main target of SSRIs.

\section{Polymorphisms in Human ITGB3 Affect Integrin $\beta 3$ Subunit Expression}

Numerous functional polymorphisms within human ITGB3 cause lack of (ie, $<5 \%$ of normal) or reduced expression of (ie, $10-20 \%$ of normal) $\alpha \mathrm{IIb} \beta 3$ receptors on the platelet surface of patients with Glanzmann thrombasthenia (GT), a rare, heritable, or autoimmune coagulopathy (Nurden et al, 2011). Given our findings that a heterozygous reduction in integrin $\beta 3$ subunit expression reduces the effective dose of SSRIs to antagonize SERT, we performed a polymorphism 

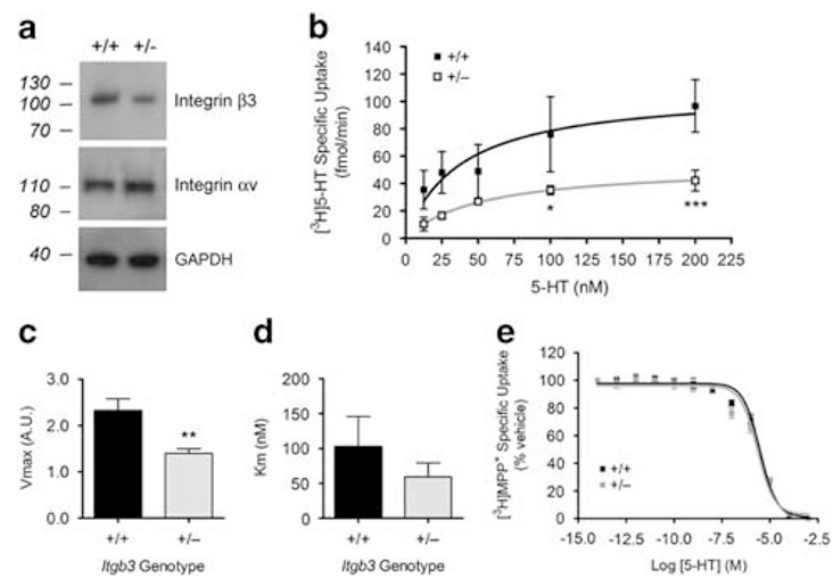

Figure 3 Integrin $\beta 3$ haploinsufficiency decreases SERT function. (a) Western blot analysis of midbrain synaptosomes from $\operatorname{ltgb} 3^{+/+}$and $\operatorname{ltgb} 3^{+-}$ mice using antibodies recognizing the integrin $\beta 3$ and $\alpha v$ subunits and GAPDH. Differences in integrin $\beta 3$ subunit expression were significant when values in the $\operatorname{ltgb} 3^{+/-}$condition were compared with $\operatorname{ltgb} 3^{+/+}$, which was set to 100. $\operatorname{tgb} 3^{+/+}=100 \pm 0.5, n=5 ; \mid \operatorname{tgb} 3^{+/-}=40.45 \pm 14.7, n=6$. Unpaired $t$-test with Welch's correction: $P=0.009$. Representative data from three independent experiments. (b) Representative kinetic saturation analysis experiment of $\left[{ }^{3} \mathrm{H}\right]$ 5-HT specific uptake by SERT in Itgb3 ${ }^{+/+}$(black) or ltgb $3^{+1-}$ (gray) midbrain synaptosomes. Two-way ANOVA Bonferroni post-test: $* P<0.05$; **** $P<0.001$. $\operatorname{ltgb} 3^{+/+}, n=4 ; \operatorname{tg} b 3^{+/-}, n=3$. (c) Analysis of maximum SERT-mediated 5-HT transport velocity ( $V_{\text {max; }}$ arbitrary units (a.u.)) from pooled kinetic saturation experiments. $\operatorname{ltgb} 3^{+/+}=2.322 \pm 0.258, n=13 ; \operatorname{ltg} b 3^{+/}$ $=1.402 \pm 0.098, n=15$. Unpaired $t$-test with Welch's correction: $P=0.0045$. (d) Analysis of SERT affinity for $5-H T\left(K_{m}\right)$ from pooled kinetic saturation experiments. $\operatorname{ltgb} 3^{+/+}=102.4 \pm 43.5, n=13 ; \operatorname{ltg} 3^{+/-}=59.4 \pm 20.0, n=15$. Unpaired $t$-test with Welch's correction was non-significant. (e) Competition uptake curves for $\left[{ }^{3} \mathrm{H}\right] \mathrm{I}$-methyl-4-phenylpyridinium $\left(\left[^{3} \mathrm{H}\right] \mathrm{MPP}^{+}\right)$with $5-\mathrm{HT}$ in $\operatorname{ltgb} 3^{+/+}$(black) or Itgb3 $3^{+/-}$(gray) midbrain synaptosomes. Itgb3 ${ }^{+/+}$: Logic50: $-5.528 \pm 0.059, n=4 . \operatorname{ltgb}^{+1-}: \log _{\mid c 50}:-5.655 \pm 0.083, n=4$. Data presented as means \pm SEM. ANOVA, analysis of variance; GAPDH, glyceraldehyde 3-phosphate dehydrogenase; HT, hydroxytryptamine; SERT, serotonin transporter.

screen in patients that do not have GT to identify single nucleotide polymorphisms (SNPs) in ITGB3 that reduce integrin $\beta 3$ subunit expression. We tested for association of three common SNPs, rs 2317385 ( $3475 \mathrm{G}>\mathrm{A}$, in the $5^{\prime} \mathrm{UTR}$ ), rs15908 (42130 A > C, Val381Val, in exon 9), and rs12603582 $(51370 \mathrm{G}>\mathrm{T}$, in intron 11), with altered platelet expression of the integrin $\beta 3$ subunit. Our findings revealed a significant reduction in integrin $\beta 3$ subunit protein levels in the CC homozygous genotype at rs15908 with no alteration in SERT or GAPDH expression (Table 1). We also observed significant reductions in integrin $\beta 3$ protein levels for the AA genotype of rs2317385, although this is likely driven by an extremely small sample size. For rs12603582, no statistically significant change in integrin $\beta 3$ subunit, SERT, or GAPDH expression was observed in patients carrying the minor allele (Table 1). These data suggest that the difference in integrin $\beta 3$ subunit expression in the haploinsufficient mouse is relevant to genetic variation in human patients without a coagulopathy.

\section{DISCUSSION}

Evidence documenting the association of ITGB3 with whole blood 5-HT levels, replicated by multiple laboratories (Weiss

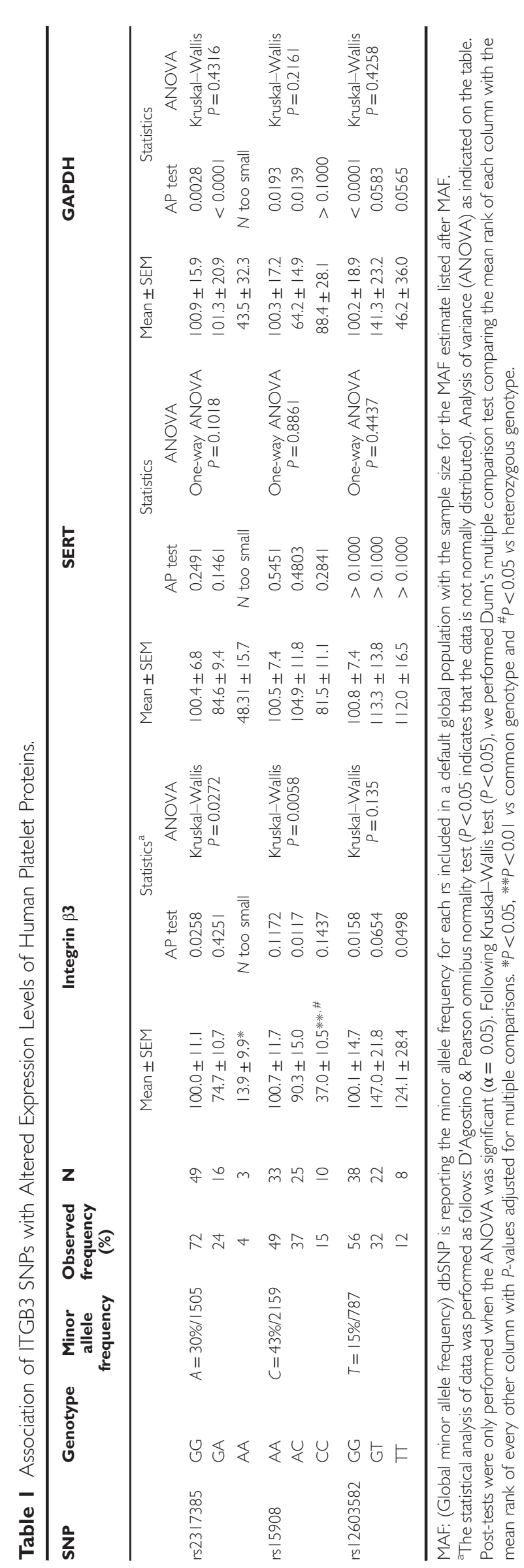


a

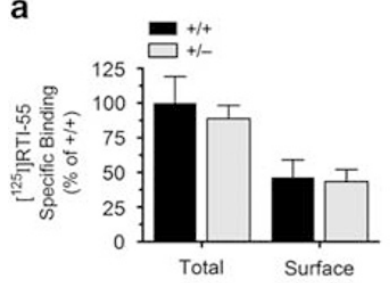

C
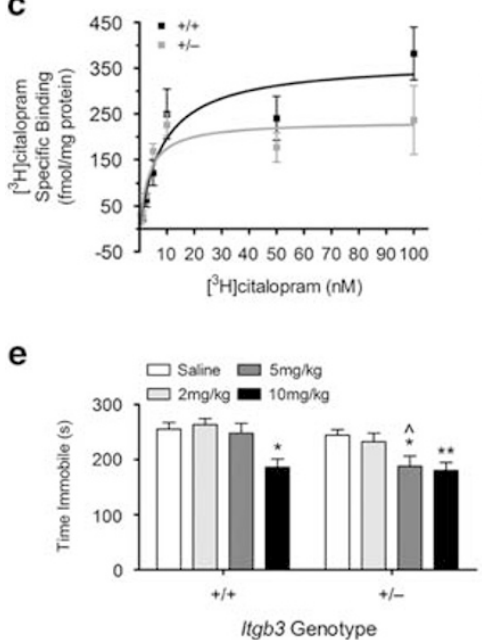

b

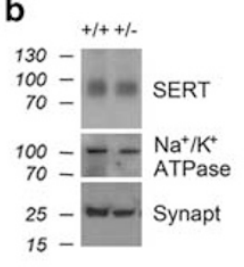

d

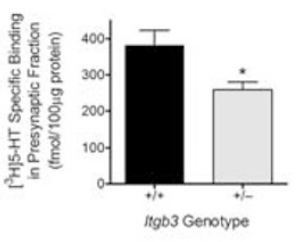

f

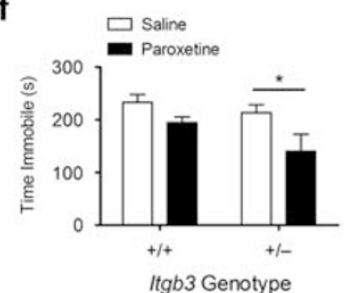

Figure 4 Itgb3 haploinsufficiency decreases the number of active SERT molecules and effective SSRI dose. (a) Radioligand displacement assays using $\left.{ }^{125}\right]$ RTI-55 identified levels of total SERT (Total) and plasma membrane-localized SERT (Surface) in the presence of excess paroxetine and $5-\mathrm{HT}$, respectively. $\operatorname{ltg} b 3^{+/+}, n=4 ; \operatorname{ltg} b 3^{+/-}, n=4$. (b) Representative western blot of purified presynaptic plasma membranes using antibodies recognizing SERT, $\mathrm{Na}^{+} / \mathrm{K}^{+}$-ATPase, and synaptophysin (Synapt). SERT values in the $\operatorname{lgb} 3^{+/-}$condition were compared with $\operatorname{lgb} 3^{+/+}$: $\left|\operatorname{tgb} 3^{+/+}=108.8 \pm 24.0, n=5 ;\right| \operatorname{tg} b 3^{+1-}=|17| \pm.|6|,. n=5$. (c) Saturation analysis of $\left[{ }^{3} \mathrm{H}\right]$ citalopram $(0.625-100 \mathrm{nM})$ binding to presynaptic plasma membranes purified from ltgb $3^{+/+}$(black) and ltgb $3^{+-}$(gray) synaptosomes. $B_{\max }\left|\operatorname{tg} b 3^{+/+}=365.2 \pm 42.69, n=3 ;\right| \operatorname{tg} b 3^{+/}=233.6 \pm 24.56, n=4$. Unpaired t-test with Welch's correction: $P=0.0761$. (d) Radioligand binding assays with $20 \mathrm{nM}\left[{ }^{3} \mathrm{H}\right] 5-\mathrm{HT}$ were performed on ltgb3 ${ }^{+/+}$(black) and $\operatorname{ltgb} 3^{+1-}$ (gray) presynaptic plasma membranes. $\operatorname{ltg} 3^{+/+}=381.3 \pm 41.96$, $n=7 ; \quad \operatorname{tgb} 3^{+1-}=258.6 \pm 21.50, n=5$. Unpaired $t$-test with Welch's correction: $P=0.0315$. (e) Mice were administered saline or citalopram at doses of 2, 5 , or $10 \mathrm{mg} / \mathrm{kg}$ and then the immobility times of animals in the tail suspension test were recorded. Asterisks represent drug effects within genotype comparisons: ${ }^{*} P<0.05$ and $* * P<0.01$. Carrots represent genotype comparisons within each dose: $\wedge p<0.05$. Saline: $\operatorname{ltgb} 3^{+1+}=259.9 \pm 11.3, n=16 ; \operatorname{ltgb} 3^{+/-}=244.4 \pm 10.0, n=23$. Two-way RM ANOVA citalopram effect: $F_{(3.148)}=8.11, \quad P<0.0001 .5 \mathrm{mg} / \mathrm{kg}$ : $\mid \operatorname{tgb} 3^{+/+}=248.6 \pm 14.6, n=16 ; \operatorname{ltgb} 3^{+/}=194.9 \pm 17.6, n=23$. Bonferroni post-test: $\quad * P=0.0246, \quad \wedge P=0.0358 . \quad 10 \mathrm{mg} / \mathrm{kg}: \quad \mid \operatorname{tgb} 3^{+/+}=183.2 \pm$ 14.2, $\quad n=16 ; \quad \mid \operatorname{tgb} 3^{+1-}=180.3 \pm 14.4, \quad n=23$. Bonferroni post-test: $\operatorname{ltgb} 3^{+/+}=* P=0.0417, \operatorname{ltgb} 3^{+1-}=* * P=0.0055$. (f) Mice were administered saline or $5 \mathrm{mg} / \mathrm{kg}$ paroxetine and then the immobility times of animals in the tail suspension test were recorded. $\operatorname{ltgb} 3^{+/+}{ }_{\text {saline }}=233.0 \pm 15.0, n=9$; $\mid \operatorname{tgb} 3^{+/+}$paroxetine $=194.7 \pm 10.6, n=6 ; \quad \operatorname{tgb} 3^{+/-}{ }_{\text {saline }}=213.6 \pm 15.0, n=9$; Itgb $^{+/}$paroxetine $=140.5 \pm 32.1, n=5$. Two-way ANOVA paroxetine effect $F(1,25)=9.29, \quad P<0.005$. Bonferroni post-test: $\operatorname{ltgb3}^{+/-}$saline vs Itgb $3^{+/}$paroxetine $* P=0.0220$. Data presented as means \pm SEM. ANOVA, analysis of variance; $H T$, hydroxytryptamine; RM, repeated measures; SERT, serotonin transporter; SSRI, selective serotonin reuptake inhibitor.

et al, 2004, 2006a, 2006b; Coutinho et al, 2007; Cross et al, 2008; Napolioni et al, 2011) led us to examine whether haploinsufficiency in the integrin $\beta 3$ gene modulates SERT function in the CNS. In contrast to studies in platelets,

disruption of a single Itgb3 allele in mice was sufficient to dramatically diminish 5-HT uptake by SERT in raphe synaptosomes, indicating that serotonergic signaling in the $\mathrm{CNS}$ is more sensitive to alterations in integrin $\beta 3$ subunit expression (Carneiro et al, 2008). Assays to delineate the mechanism(s) behind the changes in SERT's kinetic properties revealed that integrin $\alpha \mathrm{v} \beta 3$ receptors play a permissive role in determining the number of active SERT molecules. Finally, we identified the common ITGB3 allelic variant rs15908, a silent SNP in exon 9, which significantly decreases expression of the integrin $\beta 3$ subunit in homozygotes without generating a thrombocytopathic phenotype.

Many previous studies have demonstrated that several integrin subunits (eg, $\beta 1, \beta 3, \beta 5, \beta 8$, and $\alpha \mathrm{v}$ ) localize to neuronal post-synaptic densities in hippocampal neurons (Nishimura et al, 1998; Chan et al, 2003; Kramar et al, 2003; Chan et al, 2006; Pozo et al, 2012). However, few have examined their potential to localize to presynaptic membranes within neurotransmitter-specific projections. Immunofluorescent microscopy and subcellular fractionation analysis of the distribution of integrin $\beta 3$ subunits in adult mouse midbrains revealed that integrin $\alpha v \beta 3$ receptors are expressed in a subpopulation of presynaptic terminals of serotonergic neurons. Interestingly, structured illumination microscopy revealed instances whereby an $\alpha \mathrm{v} \beta 3$ receptor and SERT molecule co-localized within subcellular compartments, suggesting they may participate in a multiprotein complex, akin to the $\alpha \mathrm{IIb} \beta 3$ SERT complexes observed in platelets (Carneiro et al, 2008).

In the periphery, integrin $\alpha v \beta 3$ plays a pivotal role in the modulation of intracellular signaling initiated by several receptor systems, including GPCRs, RTKs, and ionotropic receptors. To date, few studies have dissected the signaling pathways influenced by $\alpha \mathrm{v} \beta 3$ signaling in neurons, but several canonical pathways typically associated with integrin engagement and clustering could potentially modulate SERT activity. One such candidate, the p38 MAPK pathway, is activated by integrin-linked kinase downstream of $\alpha \mathrm{v} \beta 3$ and can modulate SERT's catalytic activity in a manner independent of changes in SERT trafficking (Zhu et al, 2005; Wang et al, 2010; Chang et al, 2012; Yu et al, 2014). However, attempts to activate p38 MAPK with anisomycin failed to rescue the phenotype observed in $\operatorname{Itgb3}{ }^{+/-}$(data not shown). On the other hand, $\alpha \mathrm{v} \beta 3$ receptors may regulate SERT activity via a mobilitymediated mechanism. In glycinergic synapses, the disruption of actin filaments dramatically alters integrin $\alpha \mathrm{v} \beta 3$-mediated modulation of glycine receptor movement (Charrier et al, 2010). Similarly, the actin cytoskeleton has been shown to restrict the lateral diffusion of SERTs at the plasma membrane of serotonergic synapses, which correlates with reduced 5-HT uptake (Chang et al, 2012). Future studies should clarify the extent to which a signaling-based and/or mobility-based mechanism of SERT regulation is employed by $\alpha \mathrm{v} \beta 3$ receptors in serotonergic synapses of the midbrain.

Despite their efficacy in treating several neuropsychiatric diseases, SSRIs fail to sufficiently address symptoms in approximately two-thirds of patients (Katzman, 2009; Kennedy et al, 2009; Montgomery et al, 2011). Our studies on Itgb3 have revealed that a reduction in integrin $\beta 3$ subunit expression is sufficient to decrease the effective dose of acutely administered citalopram and paroxetine in adult 
mice, as measured by TSTs; thus implicating a deterministic role for ITGB3 polymorphisms in the response of human patients to SSRIs. The TST has been widely used to predict antidepressant response in rodents, and we have modified the behavior to prevent C57BL/6 mice from climbing their tail, a major disadvantage of the test (Cryan et al, 2005). Complementary studies in other behavioral tests, such as the FST, were complicated by a severe response of $\operatorname{Igb} 3^{+/-}$mice to either the intraperitoneal injections or the hypothermic exposure of the test (data not shown). The reduced 5-HT binding in plasma membranes isolated from $\operatorname{Itgb3}^{+/-}$ synaptosomes indicates that fewer SERT molecules are catalytically able to actively transport $5-\mathrm{HT}$; suggesting that lower doses of SSRIs can antagonize the remaining active SERT molecules. Our immunolocalization studies support the notion that $\alpha \mathrm{v} \beta 3$ receptors specify a subpopulation of SERT molecules that may represent the main target of SSRIs, losing complete catalytic function in the absence of $\alpha \mathrm{v} \beta 3$ receptors. Ascertaining if the $\alpha \mathrm{v} \beta 3$-expressing serotonergic synapses are common to all serotonergic neurons or are derived from a subpopulation of serotonergic neurons could further our understanding of neuropsychiatric disease states (Hale et al, 2012).

The human ITGB3 locus has been extensively characterized in the context of thrombosis and, more recently, autism, leading to the validation of over 1,500 variants (NCBI, dbSNP, validated by 1000 Genomes). The prevalence of patients who are antidepressant partial-responders or nonresponders warrants a further look at ITGB3 polymorphisms as they relate to neuropsychiatric disorders, especially since common variants (including rs15908, which we identified here) as well as rare loss-of-function variants in ITGB3 are observed in humans. Future studies should aim to determine if carriers of human ITGB3 coding variants demonstrate altered risk for neuropsychiatric disorders commonly associated with dysfunction in 5-HT as well as altered SSRI effectiveness in the treatment of various neuropsychiatric diseases. The predictive value of the TST is somewhat limited, and may reflect changes occurring in the early stages of antidepressant treatment, such as fear perception (Harmer et al, 2003). Given that the complexity of neural circuitry appears to be a reflection of synaptic diversity, characterizing the molecular differences between populations of $\alpha \mathrm{v} \beta 3$ expressing and non- $\alpha \mathrm{v} \beta 3$-expressing serotonergic synapses could advance the development of novel, more efficacious antidepressants.

\section{FUNDING AND DISCLOSURE}

NARSAD YI AWARD (AMDC), MH090256 (AMDC), MH081066 (JV-VW), Vanderbilt Postdoctoral Training Grant in Functional Neurogenomics (T32-MH65215) (MM). Human platelet western blots were funded in part by a grant from the Vanderbilt CTSA (UL1TR000445, KL2TR000446, and TL1TR000447). JV-VW has consulted with Roche, Novartis, and SynapDx and has received research funding from Roche, Novartis, SynapDx, Seaside Therapeutics, Forest, and Sunovion for unrelated work. The authors declare that over the past 3 years EHJC has received compensation from Seaside Therapeutics for consultation and support of clinical trial research that is unrelated to the work covered in the submission.

\section{ACKNOWLEDGMENTS}

We would like to acknowledge Jon Allison for general administration and organization of the Vanderbilt Murine Neurobehavioral core, and Jennifer Schafer for assistance with the super resolution microscopy. We also thank Michael Dohn for animal husbandry, general laboratory administration, and assistance with editing of the manuscript.

\section{REFERENCES}

Arai R, Karasawa N, Kurokawa K, Kanai H, Horiike K, Ito A (2002). Differential subcellular location of mitochondria in rat serotonergic neurons depends on the presence and the absence of monoamine oxidase type B. Neuroscience 114: 825-835.

Askenazy F, Candito M, Caci H, Myquel M, Chambon P, Darcourt G et al (1998). Whole blood serotonin content, tryptophan concentrations, and impulsivity in anorexia nervosa. Biol Psychiatry 43: 188-195.

Blakely RD, Ramamoorthy S, Schroeter S, Qian Y, Apparsundaram S, Galli A et al (1998). Regulated phosphorylation and trafficking of antidepressant-sensitive serotonin transporter proteins. Biol Psychiatry 44: 169-178.

Carneiro AM, Cook EH, Murphy DL, Blakely RD (2008). Interactions between integrin alphaIIbbeta3 and the serotonin transporter regulate serotonin transport and platelet aggregation in mice and humans. J Clin Invest 118: 1544-1552.

Carter MD, Shah CR, Muller CL, Crawley JN, Carneiro AM, Veenstra-VanderWeele J (2011). Absence of preference for social novelty and increased grooming in integrin beta 3 knockout mice: initial studies and future directions. Autism Res 4: 57-67.

Chan CS, Weeber EJ, Kurup S, Sweatt JD, Davis RL (2003). Integrin requirement for hippocampal synaptic plasticity and spatial memory. J Neurosci 23: 7107-7116.

Chan CS, Weeber EJ, Zong L, Fuchs E, Sweatt JD, Davis RL (2006). Beta 1-integrins are required for hippocampal AMPA receptordependent synaptic transmission, synaptic plasticity, and working memory. J Neurosci 26: 223-232.

Chang JC, Tomlinson ID, Warnement MR, Ustione A, Carneiro AM, Piston DW et al (2012). Single molecule analysis of serotonin transporter regulation using antagonist-conjugated quantum dots reveals restricted, p38 MAPK-dependent mobilization underlying uptake activation. J Neurosci 32: 8919-8929.

Charrier C, Machado P, Tweedie-Cullen RY, Rutishauser D, Mansuy IM, Triller A (2010). A crosstalk between betal and beta3 integrins controls glycine receptor and gephyrin trafficking at synapses. Nat Neurosci 13: 1388-1395.

Chavis P, Westbrook G (2001). Integrins mediate functional preand postsynaptic maturation at a hippocampal synapse. Nature 411: 317-321.

Cingolani LA, Thalhammer A, Yu LM, Catalano M, Ramos T, Colicos MA et al (2008). Activity-dependent regulation of synaptic AMPA receptor composition and abundance by beta3 integrins. Neuron 58: 749-762.

Cleare AJ (1997). Reduced whole blood serotonin in major depression. Depress Anxiety 5: 108-111.

Cook EH, Leventhal BL (1996). The serotonin system in autism. Curr Opin Pediatr 8: 348-354.

Coutinho AM, Sousa I, Martins M, Correia C, Morgadinho T, Bento C et al (2007). Evidence for epistasis between SLC6A4 and ITGB3 in autism etiology and in the determination of platelet serotonin levels. Hum Genet 121: 243-256.

Cross S, Kim SJ, Weiss LA, Delahanty RJ, Sutcliffe JS, Leventhal BL et al (2008). Molecular genetics of the platelet serotonin system in first-degree relatives of patients with autism. Neuropsychopharmacology 33: 353-360. 
Cryan JF, Mombereau C, Vassout A (2005). The tail suspension test as a model for assessing antidepressant activity: review of pharmacological and genetic studies in mice. Neurosci Biobehav Rev 29: 571-625.

DeLisi LE, Neckers LM, Weinberger DR, Wyatt RJ (1981). Increased whole blood serotonin concentrations in chronic schizophrenic patients. Arch Gen Psychiatry 38: 647-650.

Hale MW, Shekhar A, Lowry CA (2012). Stress-related serotonergic systems: implications for symptomatology of anxiety and affective disorders. Cell Mol Neurobiol 32: 695-708.

Hammock E, Veenstra-VanderWeele J, Yan Z, Kerr TM, Morris M, Anderson GM et al (2012). Examining autism spectrum disorders by biomarkers: example from the oxytocin and serotonin systems. J Am Acad Child Adolesc Psychiatry 51: 712-721 e711.

Harmer CJ, Bhagwagar Z, Perrett DI, Vollm BA, Cowen PJ, Goodwin GM (2003). Acute SSRI administration affects the processing of social cues in healthy volunteers. Neuropsychopharmacology 28: 148-152.

Henry LK, Field JR, Adkins EM, Parnas ML, Vaughan RA, Zou MF et al (2006). Tyr-95 and Ile-172 in transmembrane segments 1 and 3 of human serotonin transporters interact to establish high affinity recognition of antidepressants. J Biol Chem 281: 2012-2023.

Hodivala-Dilke KM, McHugh KP, Tsakiris DA, Rayburn H, Crowley D, Ullman-Cullere $\mathrm{M}$ et al (1999). Beta3-integrindeficient mice are a model for Glanzmann thrombasthenia showing placental defects and reduced survival. J Clin Invest 103: 229-238.

Katzman MA (2009). Current considerations in the treatment of generalized anxiety disorder. CNS Drugs 23: 103-120.

Kennedy SH, Andersen HF, Thase ME (2009). Escitalopram in the treatment of major depressive disorder: a meta-analysis. Curr Med Res Opin 25: 161-175.

Kramar EA, Bernard JA, Gall CM, Lynch G (2003). Integrins modulate fast excitatory transmission at hippocampal synapses. J Biol Chem 278: 10722-10730.

Ma N, Tan LW, Wang Q, Li ZX, Li LJ (2007). Lower levels of whole blood serotonin in obsessive-compulsive disorder and in schizophrenia with obsessive-compulsive symptoms. Psychiatry Res 150: 61-69.

Mayorga AJ, Dalvi A, Page ME, Zimov-Levinson S, Hen R, Lucki I (2001). Antidepressant-like behavioral effects in 5-hydroxytryptamine(1A) and 5-hydroxytryptamine(1B) receptor mutant mice. J Pharmacol Exp Ther 298: 1101-1107.

Milner R, Campbell IL (2002). The integrin family of cell adhesion molecules has multiple functions within the CNS. J Neurosci Res 69: 286-291.

Montgomery S, Hansen T, Kasper S (2011). Efficacy of escitalopram compared with citalopram: a meta-analysis. Int J Neuropsychopharmacol 14: 261-268.

Napolioni V, Lombardi F, Sacco R, Curatolo P, Manzi B, Alessandrelli R et al (2011). Family-based association study of ITGB3 in autism spectrum disorder and its endophenotypes. Eur J Hum Genet 19: 353-359.

Nikonenko I, Toni N, Moosmayer M, Shigeri Y, Muller D, Sargent Jones L (2003). Integrins are involved in synaptogenesis, cell spreading, and adhesion in the postnatal brain. Brain research. Dev Brain Res 140: 185-194.

Nishimura SL, Boylen KP, Einheber S, Milner TA, Ramos DM, Pytela R (1998). Synaptic and glial localization of the integrin alphavbeta8 in mouse and rat brain. Brain Res 791: 271-282.

Nurden AT, Fiore M, Nurden P, Pillois X (2011). Glanzmann thrombasthenia: a review of ITGA2B and ITGB3 defects with emphasis on variants, phenotypic variability, and mouse models Blood 118: 5996-6005.

Phillips GR, Huang JK, Wang Y, Tanaka H, Shapiro L, Zhang W et al (2001). The presynaptic particle web: ultrastructure, composition, dissolution, and reconstitution. Neuron 32: 63-77.

Pozo K, Cingolani LA, Bassani S, Laurent F, Passafaro M, Goda Y (2012). beta3 integrin interacts directly with GluA2 AMPA receptor subunit and regulates AMPA receptor expression in hippocampal neurons. Proc Natl Acad Sci USA 109: 1323-1328.

Pozzi A, Zent R (2003). Integrins: sensors of extracellular matrix and modulators of cell function. Nephron Exp Nephrol 94: e77-e84.

Ramaiya A, Johnson JH, Karnes HT (1997). Evaluation of the neuropharmacodynamics of paroxetine in vivo utilizing microdialysis. J Pharm Sci 86: 1497-1500.

Ruhe HG, Mason NS, Schene AH (2007). Mood is indirectly related to serotonin, norepinephrine and dopamine levels in humans: a meta-analysis of monoamine depletion studies. Mol Psychiatry 12: 331-359.

Verkes RJ, Hengeveld MW, van der Mast RC, Fekkes D, van Kempen GM (1998). Mood correlates with blood serotonin, but not with glucose measures in patients with recurrent suicidal behavior. Psychiatry Res 80: 239-248.

Wang R, Li ZQ, Han X, Li BL, Mi XY, Sun LM et al (2010). Integrin beta 3 and its ligand regulate the expression of uPA through p38 MAPK in breast cancer. APMIS 118: 909-917.

Weiss LA, Kosova G, Delahanty RJ, Jiang L, Cook EH, Ober C et al (2006a). Variation in ITGB3 is associated with whole-blood serotonin level and autism susceptibility. Eur J Hum Genet 14: 923-931.

Weiss LA, Ober C, Cook EH Jr (2006b). ITGB3 shows genetic and expression interaction with SLC6A4. Hum Genet 120: 93-100.

Weiss LA, Veenstra-Vanderweele J, Newman DL, Kim SJ, Dytch H, McPeek MS Jr et al (2004). Genome-wide association study identifies ITGB3 as a QTL for whole blood serotonin. Eur J Hum Genet 12: 949-954.

Whyte A, Jessen T, Varney S, Carneiro AM (2014). Serotonin transporter and integrin beta 3 genes interact to modulate serotonin uptake in mouse brain. Neurochem Int 73: 122-126.

Wulsin LR, Musselman D, Otte C, Bruce E, Ali S, Whooley MA (2009). Depression and whole blood serotonin in patients with coronary heart disease from the Heart and Soul Study. Psychosom Med 71: 260-265.

Yu L, Yuan X, Wang D, Barakat B, Williams ED, Hannigan GE (2014). Selective regulation of p38beta protein and signaling by integrin-linked kinase mediates bladder cancer cell migration. Oncogene 33: 690-701.

Zhu CB, Blakely RD, Hewlett WA (2006). The proinflammatory cytokines interleukin-1beta and tumor necrosis factor-alpha activate serotonin transporters. Neuropsychopharmacology 31: 2121-2131.

Zhu CB, Carneiro AM, Dostmann WR, Hewlett WA, Blakely RD (2005). p38 MAPK activation elevates serotonin transport activity via a trafficking-independent, protein phosphatase $2 \mathrm{~A}$-dependent process. J Biol Chem 280: 15649-15658.

Zhu CB, Hewlett WA, Feoktistov I, Biaggioni I, Blakely RD (2004). Adenosine receptor, protein kinase $\mathrm{G}$, and p38 mitogen-activated protein kinase-dependent up-regulation of serotonin transporters involves both transporter trafficking and activation. Mol Pharmacol 65: 1462-1474.

Zhu CB, Lindler KM, Owens AW, Daws LC, Blakely RD, Hewlett WA (2010). Interleukin-1 receptor activation by systemic lipopolysaccharide induces behavioral despair linked to MAPK regulation of CNS serotonin transporters. Neuropsychopharmacology 35: $2510-2520$.

Supplementary Information accompanies the paper on the Neuropsychopharmacology website (http://www.nature.com/npp) 